\title{
Pengembangan Perangkat Pembelajaran Matematika Berbasis Konstruktivisme
}

\author{
G. Gunawan \\ Universitas PGRI Yogyakarta. Jalan. PGRI Sonosewu No. 117, Yogyakarta, Indonesia. \\ Email: tugaskuliahgun@gmail.com, Telp: +62274-376808
}

Received: 20 May 2017; Revised:7 June 2017; Accepted: 10 June 2017

\begin{abstract}
Abstrak
Penelitian ini bertujuan untuk menghasilkan perangkat pembelajaran matematika SMP berbasis konstruktivisme yang valid, praktis, dan efektif. Penelitian ini merupakan penelitian pengembangan dengan mengacu pada langkah yang dikembangkan oleh Thiagarajan. Prosedur pengembangan terdiri atas 4 tahap yang meliputi: (a) pendefinisian (define), (b) perancangan (design), (c) pengembangan (develop), dan (d) penyebaran (dissemination). Hasil penelitian menunjukkan perangkat pembelajaran yang dikembangkan yakni Rencana Pelaksanaan Pembelajaran (RPP), Buku Guru (BG), Buku Sisa (BS), Lembar Kegiatan Siswa (LKS), dan Tes Hasil Belajar (THB) layak digunakan dengan kategori valid. Dari uji coba menunjukkan perangkat yang dikembangkan telah memenuhi kriteria kepraktisan dan keefektifan. Tingkat kepraktisan pada setiap pembelajaran sebagai berikut; (1) kepraktisan menurut guru berkategori sangat praktis, (2) kepraktisan menurut siswa berkategori praktis, (3) hasil observasi kemampuan guru menunjukkan kategori baik, (4) aktivitas siswa berkategori sangat baik. Keefektifan perangkat pembelajaran ditunjukkan oleh: (1) tes hasil belajar siswa dengan tingkat kelulusan kategori sangat efektif, (2) respon siswa terhadap pembelajaran menunjukkan kategori sangat baik, (3) respon guru berkategori sangat baik.
\end{abstract}

Kata Kunci: perangkat pembelajaran,konstruktivisme

\section{Developing Mathematics Learning Kits Based on Contructivism}

\begin{abstract}
This research aimed to producing mathematics learning kits for junior high school based on constructivism teaching and learning approach that was valid, practical, and effective. This research $\&$ development refered to the step developed by Thiagarajan, that included (a) define, (b) design, (c) develop, and $(d)$ disseminate phase. The results showed that the developed learning kits consisting of lesson plans, teacher's guidebook, student's book, student's worksheet, and learning achievement test were qualified with valid category. The results of tryout showed that the developed learning device gain the criteria for practicality and effectiveness, with degrees of practicality as follows (1) teacher's evaluation sheets of practicality was very practical; (2) student's evaluation sheet of practicality showed the learning kits in a good category. (3) The result of observation sheet showed teachers' competence in a good category. (4) The students' activities were very good category. The effectiveness is indicated by: (1) the students passing the learning achievement test; (2) the students' responses are in a very good category; and (3) the teachers' responses are in a very good category.
\end{abstract}

Keywords: learning device, constructivism

How to Cite: Gunawan, G. (2017). Pengembangan perangkat pembelajaran matematika SMP berbasis konstruktivisme. PYTHAGORAS: Jurnal Pendidikan Matematika, $\quad 12(1), \quad 47-56$. doi:http://dx.doi.org/10.21831/pg.v12i1.14054

Permalink/DOI: http://dx.doi.org/10.21831/pg.v12i1.14054 


\section{PENDAHULUAN}

Pendidikan dipahami sebagai usaha manusia yang bersifat membangun, menciptakan dan memahami makna pengetahuan yang dipelajari sesuai dengan pengalaman seseorang. Pemahaman terhadap makna dari pengetahuan yang dipelajari mampu menciptakan manusia yang mempunyai pengetahuan lebih dinamis.

Salah satu faktor yang mempunyai pengaruh cukup besar dalam pencapaian hasil belajar adalah pendekatan yang digunakan saat proses pembelajaran berlangsung. Pendekatan pembelajaran dapat dijadikan sebagai titik tolak atau sudut pandang terhadap proses pembelajaran, yang merujuk pada pandangan tentang terjadinya suatu proses yang sifatnya masih sangat umum, di dalamnya mewadahi, menginsiprasi, menguatkan, dan melatari metode pembelajaran dengan cakupan teoretis tertentu

Matematika sebagai salah satu mata pelajaran, berfungsi mengembangkan kemampuan menghitung, mengukur, dan menggunakan rumus matematika dalam kehidupan sehari-hari. Matematika sebagai salah satu disiplin ilmu, menjadi pendukung bagi keberadaan ilmu-ilmu yang lain (Muijs \& Reynold, 2011, p.256). Matematika berkenaan dengan ide-ide (gagasangagasan dan struktur-struktur) dan hubungannya diatur secara logika. Matematika berkaitan dengan konsep abstrak, hal tersebut membuat siswa merasa kesulitan dalam mempelajarinya. Siswa lebih mudah mempelajari hal-hal yang bersifat konkrit, sehingga muncul anggapan bahwa matematika merupakan salah satu mata pelajaran yang sulit dan cenderung ditakuti siswa. Pandangan ini menuntut ketepatan pendekatan dalam pembelajaran. Salah satu pendekatan yang diharapkan dapat menghasilkan output yang unggul dalam bidang pendidikan adalah pendekatan konstruktivisme. Hal tersebut sejalan dengan pendapat Glasesfeld (2003, p.66) yang menyatakan bahwa pengetahuan yang diperoleh adalah hasil kontruksi yang dilakukan oleh diri sendiri.

Konstruktivisme pada dasarnya memahami bahwa pengetahuan yang baru adalah hasil dari proses membangun atau mengkonstruksi pengetahuan yang baru dengan pengetahuan yang didapat dari pengalaman sebelumnya. David Hume menerangkan bahwa pengetahuan itu berasal dari persepsi yang diperoleh dari pengalaman yang berulang. Sedangkan Kant, menerangkan bahwa
.... the relation of cause and effect was a 'synthetic a priori' category, inherent from the outset in our thinking. He did not mean that it was innate or God-given in the sense of a Platonic idea, but rather that it was one of those heuristic fictions that reason needed in order to generate a rational picture of itself as the producer of understanding. (Glasersfeld, 2003, p.42 ).

Hubungan sebab dan akibat adalah suatu bentuk sintetik apriori yang melekat dari awal dalam pemikiran. Hal tersebut tidak berarti bahwa itu berasal dari bawaan, tetapi merupakan alasan heuristik yang diperlukan untuk menghasilkan gambaran rasional itu sendiri untuk menghasilkan pemahaman.

Pendapat tersebut merupakan pendapat tokoh yang memberikan pemikirannya tentang konstruktivisme. Berdasarkan pendapat dari tokoh tersebut dapat dipahami bahwa pembelajaran akan lebih mudah bila didasari pada apa yang diketahui siswa atau berdasarkan pengalaman siswa sebelumnya. Hal ini disebabkan karena untuk mempelajari suatu materi matematika yang baru, pengalaman belajar yang lalu dari seseorang akan mempengaruhi terjadinya proses belajar materi matematika pada saat ini (Hudojo, 1998, p.7).

Prinsip mendasar dalam pandangan konstruktivis menurut Suparno (1997, p.73) antara lain (1) pengetahuan dibangun sendiri oleh siswa secara aktif, (2) tekanan dalam proses belajar terletak pada siswa, (3) mengajar adalah membantu siswa dalam belajar, (4) tekanan dalam proses belajar lebih pada proses bukan pada hasil, (5) kurikulum menekankan pada partisipasi siswa, dan (6) guru sebagai fasilitator. Terlihat bahwa pembelajaran yang dilakukan memberikan kesempatan yang seluasluasnya kepada siswa untuk belajar secara aktif sementara guru, sebagai fasilitator belajar, menyediakan kebutuhan serta menentukan pendekatan dan model pembelajaran. Dengan demikian, diharapkan pembelajaran dengan pendekatan kontruktivisme dapat berdampak pada perubahan dalam diri siswa. Perubahan tersebut antara lain bertambahnya pengetahuan siswa, perubahan pemahaman siswa, sikap, tingkah laku, keterampilan, kecakapan, dan kemampuannya ke arah yang lebih baik.

Pendekatan dan metode pembelajaran yang tepat akan memudahkan guru dan siswa dalam proses pembelajaran. Pada dasarnya, kegiatan pembelajaran adalah kegiatan memahami 
sesuatu dan memecahkan persoalan sehingga diperoleh hasil yang lebih baik. Pikiran dari banyak orang biasanya lebih sempurna daripada satu orang. Pembelajaran yang melibatkan siswa untuk saling bertukar pikiran dan pendapat adalah cara yang perlu dan mendesak untuk selalu dilakukan dalam proses pembelajaran. Diskusi dalam kelompok belajar merupakan salah satu alternatif cara yang bisa ditempuh untuk mendapatkan hasil belajar yang optimal.

Diskusi atau belajar kelompok dengan menggunakan prinsip konstruktivisme merupakan cara yang lebih baik dalam belajar bersama. Dengan pembelajaran dalam kelompok, siswa memiliki kesempatan untuk aktif dalam kegiatan-kegiatan yang memfasilitasi mengkonstruksi pengetahuannya. Hal ini sejalan dengan pendapat Marsigit (2010, p.7) yang menyatakan bahwa pembelajaran yang baik adalah pembelajaran yang memfasilitasi siswa untuk mengungkapkan pertanyaan, memberikan ruang interaksi dan kegiatan siswa.

Untuk mencapai tujuan pembelajaran menggunakan pendekatan konstruktivis, siswa dapat dikelompokkan dalam kelompok-kelompok kecil. Hal ini bertujuan agar setiap siswa dapat aktif bekerja dalam kelompokya sehingga tujuan untuk meningkatkan kemauan dan kemampuan kerjasama, serta menambah keterlibatan emosional dan intelektual siswa dalam pembelajaran dapat tercapai. Salah satu strategi pembelajaran yang melibatkan aktivitas belajar secara berkelompok untuk mencapai tujuan tertentu yang dapat dipilih adalah Cooperative Learning. Hal ini sejalan dengan pendapat Nikou, Bonyadi, \& Ebrahimi (2014) yang menyataka bahwa dalam cooperatif learning siswa dapat bekerja sama secara kompetitif untuk mencapai tujuan kelompok yang tidak bisa diperoleh dengan belajar atau bekerja sendiri.

Cooperative Learning adalah salah satu strategi dalam pembelajaran yang memiliki beragam tipe. Salah satu tipe dalam cooperatf learning adalah STAD (Student Teams Achievement Devision). Model pembelajaran cooperatif learning dengan tipe STAD dapat memfasilitasi siswa dalam melakukan belajar kelompok serta berkompetisi dengan kelompok yang lain (Arends \& Kilcher, 2010, p.317). Dengan menggunakan model pembelajaran cooperatif learning tipe STAD, selain siswa dituntut untuk melakukan belajar kelompok untuk meningkatkan pemahamannya mengenai materi pembelajaran, siswa juga dituntut untuk menyumbangkan ide-ide terbaiknya dalam kelompok sehingga peningkatan pemahaman baik secara kelompok maupun individudapat meningkat dan dapat bersaing dengan kelompok-kelompok lain.

Untuk mewujudkan tujuan pembelajaran, model pembelajaran matematika berbasis konstruktivisme menjadi salah satu alternatif pilihan. Penelitian mengenai lesson study di Indonesia mengungkapkan bahwa dengan menggunakan pendekatan konstruktivisme, siswa dapat mengetahui gaya terbaik mereka belajar. Kompetisi meningkat antara kelompok siswa dalam menyajikan hasil pekerjaan mereka dan mempresentasi tugas-tugas mereka. Ini mendorong siswa untuk belajar lebih banyak. (Marsigit, 2007, p.143). Selain itu, penelitian yang dilakukan oleh Rostika (2008, p.5) mengungkapkan bahwa pembelajaran volume bangun ruang dengan menggunakan pendekatan konstruktivisme dapat meningkatkan minat belajar siswa, hal ini ditunjukkan dengan hampir setiap tindakan dalan satu siklus respon siswa terhadap pembelajaran positif, antusias, gembira, semangat, bekerjasama dan serius dalam melakukan aktivitas. Setiap tindakan dalam satu siklus mengalami peningkatan minat dan aktivitas belajar siswa. Penelitian lain menunjukkan bahwa pembelajaran dengan cooperatif learning tipe STAD dapat meningkatkan prestasi akademik siswa dan memberi kemajuan pada aspek penghargaan diri (self-esteem) siswa sebagai pelajar serta interaksi sosial dengan siswa lain. (Shininger, 2006, p.10).

Salah satu metode pembelajaran yang dapat digunakan yang cocok dengan materi bangun ruang sisi lengkung adalah dengan menggunakan model coperative learning tipe STAD. Model ini adalah model yang paling tepat untuk metode pengajaran dengan tujuan yang terdefinisi dengan hanya memiliki satu jawaban yang benar. Pengajaran yang dimaksud adalah perhitungan matematika, penggunaan bahasa dan mekanik, keterampilan geografi dan peta, serta fakta dan konsep dari ilmu pengetahuan. Akan tetapi, hal itu juga dapat digunakan dengan tujuan yang kurang terdefinisi dengan baik dengan memasukkan penilaian yang lebih terbuka, seperti essay atau keterampilan. (Azni, 2015, p.4)

STAD adalah salah satu model pembelajaran kooperatif yang paling sederhana, dan merupakan model yang paling baik untuk permulaan bagi para guru yang baru menggunakan pendekatan kooperatif (Slavin, 1995, p.71). 
Pembelajaran kooperatif tipe STAD merupakan salah satu bentuk pembelajaran kelompok dimana siswa dibagi menjadi beberapa kelompok yang heterogen, baik berdasarkan gender, ras atau etnis, serta prestasi. Setiap anggota kelompok menggunakan LKS atau media belajar lain untuk menguasai berbagai materi yang disampaikan, kemudian saling membantu untuk mempelajari berbagai materi melalui kegiatan tutoring, saling memberikan kuis, atau melaksanakan diskusi tim. Secara individual, siswa diberi kuis mingguan atau dua mingguan tentang berbagai materi akademis. Kuis-kuis ini diskor dan masing-masing individu diberi "skor kemajuan" (Arends, 2009, p.368).

Pembelajaran kooperatif tipe STAD dapat membantu meningkatkan kerja sama antara siswa. STAD adalah salah pembelajaran kooperatif yang membantu meningkatkan kerja sama dan kemampuan untuk mengatur diri dalam belajar. STAD bagus untuk meningkatkan interaksi antara siswa, meningkatkan sikap positif terhadap pembelajaran, harga diri yang lebih baik, dan meningkatkan kemampuan interpersonal. Tak hanya itu, pembelajaran menggunakan STAD dapat secara efektif meningkatkan prestasi belajar siswa (Arends, 2009; Badrun \& Hartono, 2013).

Adapun tujuan dari penelitian pengembangan ini adalah untuk mengkaji dan mengembangkan perangkat pembelajaran matematika berbasis konstruktivisme dengan menggunakan model pembelajaran kooperatif tipe Student Teams Achievement Division (STAD), serta mengetahui apakah perangkat pembelajaran hasil pengembangan telah sesuai dengan standar atau kriteria kelayakan yang dapat meningkatkan pemahaman konsep pada pembelajaran matematika materi bangun ruang sisi lengkung yang layak.

\section{METODE}

Jenis Penelitian ini adalah penelitian pengembangan atau development research. Produk yang dikembangkan antara lain Rencana Pelaksanaan Pembelajaran (RPP), buku guru (BG), buku siswa (BS), Lembar Kerja Siswa (LKS) dan tes hasil belajar (THB). Penelitian pengembangan ini merujuk pada model pengembangan Thiagarajan yang terdiri atas empat tahapan, yakni tahap (1) pendefinisian (define), (2) perancangan (design), (3) pengembangan (develop), dan (4) penyebaran (dissemination).
Penelitian ini dilaksanakan pada bulan Agustus sampai bulan September 2015 di SMP Pembangunan Piyungan Yogyakarta. Subjek dalam penelitian ini adalah siswa pada 2 kelas di SMP Pembangunan Piyungan yaitu kelas IX A dan IX B. Masing-masing kelas terdiri atas 28 siswa dan 1 guru. Kedua kelas tersebut memiliki kemampuan rata-rata pada kelas IX yang ada pada tingkat SMP di Yogyakarta.

Penelitian pengembangan ini dimulai dengan tahap pendefinisian (define). Tahap ini merupakan tahap pertama atau tahap persiapan untuk pengembangan. Tahap ini bertujuan untuk menghimpun informasi tentang permasalahanpermasalahan dasar yang terjadi pada pembelajaran matematika dan kebutuhan pembelajaran, informasi tentang proses pembelajaran, perangkat pembelajaran, strategi serta pendekatan pembelajaran yang digunakan oleh guru. Pada tahap ini dilakukan prasurvei lapangan yang berlangsung pada tanggal 4 Januari sampai 20 Januari 2015. Hasil pemberian angket kepada 20 guru (10 sekolah) di Yogyakarta menunjukkan bahwa penggunaan pendekatan pembelajaran yang dapat meningkatkan hasil belajar masih belum maksimal. Selain menggunakan angket, dilakukan wawancara kepada beberapa siswa dan guru, serta dilakukan observasi pembelajaran di kelas.

Selanjutnya, pada tahap perancangan (desain ) direncanakan suatu draf yang akan menghasilkan perangkat pembelajaran pendukung pelaksanaan model pembelajaran matematika berbasis konstruktivisme, yang meliputi buku guru (BG), buku siswa (BS), dan lembar kerja siswa (LKS). Kualitas produk yang dikembangkan mengacu kepada 3 kategori produk yang dikemukakan oleh yaitu aspek kualitas yang dilihat dari validitas, kepraktisan dan keefektifan.

Pada tahap pengembangan (develop), dilakukan pengembangan perangkat pembelajaran menggunakan model pembelajaran matematika berbasis konstruktivisme berdasarkan draf yang telah dibuat pada tahap sebelumnya. Setelah draf selesai dibuat, selanjutnya dilakukan tahap uji coba lapangan. Hasil pada tahap ini adalah sebuah produk awal (draf 1) yakni: (1) model pembelajaran matematika dengan pendekatan konstruktivisme terintegrasi pada RPP; (2) perangkat pendukung pelaksanaan model yakni BG, BS, dan LKS; dan (3) instrumen penilaian penelitian.

Tahap Uji Coba terdiri atas uji coba ahli yang dan uji coba lapangan. Uji coba ahli di- 
maksudkan untuk mengetahui tingkat kevalidan model pembelajaran dan perangkat pendukung pelaksanaan model pembelajaran yang dikembangkan. Uji coba lapangan dimaksudkan untuk melihat reliabilitas, tingkat kesulitan, dan daya beda soal pada THB. Setelah perangkat dinyatakan valid dan reliabel, selanjutnya dilakukan uji coba untuk melihat kepraktisan dan keefektifan perangkat pembelajaran matematika dengan pendekatan konstruktivisme hasil pengembangan.

Data penelitian ini berupa data kualitatif dan kuantitatif. Data kuantitatif diperoleh dari tes hasil belajar. Dan data kualitatif diperoleh dari penilaian para ahli mengenai kelayakan instrumen, data validasi ahli mengenai kevalidan produk, data dari kepraktisan produk, data dari analisis aktivitas siswa, analisis kemampuan guru mengelola pembelajaran, analisis respon siswa dan analisis respon guru.

Instrumen yang digunakan untuk mengumpulkan data pada penelitian ini masingmasing digunakan untuk menuhi kategori kevalidan, kepraktisan dan keefektifan. Instrumen dalam penelitian ini antara lain instrumen untuk penilaian kevalidan, kepraktisan dan keefektifan.

Dalam penelitian ini, penilaian kevalidan oleh validator dilakukan terhadap seluruh produk pengembangan meliputi RPP, BG, BS, LKS, dan THB. Instrumen lembar penilaian validator terhadap produk hasil pengembangan terdiri atas: Lembar Validasi Rencana Pelaksanaan Pembelajaran (RPP), Lembar Validasi Buku Guru (BG), Lembar Validasi Buku Siswa (BS), Lembar Validasi Lembar Kerja Siswa (LKS), dan Lembar Validasi Tes Hasil Belajar (THB).

Instrumen tingkat kepraktisan pada penelitian ini berupa lembar tingkat kepraktisan produk. Data yang dihimpun menggunakan instrumen ini berkaitan dengan tingkat keterlaksanaan dan kemudahan guru dan siswa dalam proses penggunaan dan penerapan produk pembelajaran hasil pengembangan. Instrumen terdiri lembar penilaian kepraktisan oleh guru, lembar penilaian kepraktisan oleh siswa, lembar observasi kemampuan guru mengelola pembelajaran matematika menggunkan metode Kooperatif Learning Tipe STAD, serta lembar aktivitas siswa. Hasil penilaian tersebut dijadikan tingkatan kepraktisan produk dan pembelajaran yang dikembangkan.

Tingkat keefektifan perangkat pembelajaran hasil pengembangan ditinjau berdasarkan kemajuan belajar, pemahaman dan prestasi belajar siswa. Untuk aspek kemajuan belajar, pemahaman dan prestasi digunakan tes hasil belajar (THB). Instrumen ini digunakan untuk memperoleh data hasil belajar siswa dalam pembelajaran yang dikembangkan. Untuk mengetahui respon siswa dan respon guru, digunakan instrumen lembar angket respon guru terhadap perangkat pembelajaran dan pelaksanaan pembelajaran matematika berbasis konstruktivisme, serta lembar angket respon siswa terhadap perangkat dan pelaksanaan pembelajaran matematika berbasis konstruktivisme.

\section{Teknik Analisis Data}

Kelayakan instrumen diperoleh dengan meminta pendapat ahli sebagai validator instrumen. Lembar validasi instrumen penelitian berisi tujuan, petunjuk pengisian, aspek penilaian dan indikator yakni; tujuan, isi dan bahasa, dengan skala nilai dengan skala likert dengan skala 5 yaitu: tidak valid (nilai 1), kurang valid (nilai 2), cukup valid (nilai 3), valid (nilai 4), dan sangat valid (5). Kesimpulan penilaian secara umum dengan tiga Kategori Layak digunakan (LD), Layak digunakan dengan revisi (LDR), Tidak layak digunakan (TLD).

Setelah memperoleh skor dari validator, selanjutnya dilakukan pengkategorian terhadap instrumen penelitian. Apabila instrumen yang dihasilkan termasuk dalam kategori minimal valid maka instrumen dapat digunakan untuk melakukan penelitian. Namun jika penilaian dari validator belum mencapai dalam kategori minimal valid, maka dilakukan perbaikan terhadap instrumen sampai mencapai kategori minimal valid.

Skor kevalidan perangkat pembelajaran yang diperoleh kemudian dihitung rata-rata nilai per aspeknya untuk setiap validator. Skor maksimum dan minimum pada kriteria kevalidan yaitu 5 dan 1. Tingkat validitas Buku Guru dan Buku Siswa ditinjau dari beberapa aspek yaitu: format buku, ilustrasi dan tata letak, isi buku, bahasa dan tulisan serta manfaat dan kegunaan buku. Validasi RPP dilakukan dengan mempertimbangkan beberapa aspek yaitu kesesuaian dengan buku model, bahasa, isi, alokasi waktu, serta manfaat dan kegunaan. Validasi LKS dilakukan dengan mempertimbangan beberapa aspek yaitu: format LKS, bahasa dan tulisan, ilustrasi dan tata letak serta manfaat dan kegunaan.

Tes Hasil Belajar (THB) yang dikembangkan dikatakan baik, jika penilaian dari 
validator menunjukkan pada kategori minimal valid. Penilaian validator terhadap Tes Hasil belajar dilakukan berdasarkan format, ilustrasi, tata letak, isi tes, bahasa dan tulisan, serta kegunaan. Untuk kesimpulan umum instrumen dapat digunakan jika pada kategori layak digunakan dengan revisi (LDR) dan layak digunakan (LD).

Selain itu, kelayakan THB juga ditinjau dari beberapa dimensi persyaratan alat ukur tes antara lain: reliabilitas, tingkat kesulitan, dan daya pembeda soal. Selain divalidasi pada ahli, dilakukan uji lapangan untuk mengetahui tingkat reliabilitas, tingkat kesulitan dan daya beda soal. Untuk menentukan koefesien reliabilitas THB digunakan rumus koefesien alpha Croanbach (Allen \& Yen, 1979 : 83) yaitu :

$\mathrm{r}=\left[\frac{\mathrm{N}}{\mathrm{N}-1}\right]\left[\frac{\sigma_{\mathrm{x}}^{2}-\sum_{\mathrm{i}=1}^{\mathrm{N}} \sigma_{\mathrm{Y}_{\mathrm{i}}}^{2}}{\sigma_{\mathrm{x}}^{2}}\right]$

Keterangan :

$\mathrm{N} \quad=$ Banyaknya belahan tes,

$\sigma_{\mathrm{x}}^{2} \quad=$ Varians skor tes,

$\sigma_{\mathrm{Y}_{\mathrm{i}}}^{2} \quad=$ Varians skor butir ke $\mathrm{i}$

Tingkat kesulitan (p) untuk essay yang mempunyai skor yang berskala. dikemukakan oleh (Nitko \& Brookhart, 2007), dihitung dengan menggunakan rumus :

$\mathrm{p}=\frac{\text { Mean tiap item }- \text { skor minimum }}{\text { skor maksimum }- \text { skor minimum }}$

Adapun kategori yang digunakan untuk menentukan jenis tingkat kesulitan butir soal adalah sebagai berikut :

$0,00-0,30$ soal tergolong sukar

$0,31-0,70$ soal tergolong sedang

$0,71-1,00$ soal tergolong mudah

Daya beda (D) soal dihitung dengan mengacu pada rumus yang dikemukakan oleh (Nitko dan Brookhart, 2007) yakni,

$\mathrm{D}=\frac{\text { Mean ke.l atas }- \text { Mean kel. bawah }}{\text { skor maks soal }- \text { skor min soal }}$

Adapun kriteria daya pembeda soal menrut Ebel (1979) adalah sebagai berikut :

0,40 - 1,00 soal diterima dengan baik

$0,30-0,39$ soal diterima tetapi perlu diperbaiki

$0,20-0,29$ soal diperbaiki

$0,19-0,00$ soal tidak dipakai

Data yang berupa skor tanggapan validator yang diperoleh melalui lembar validasi diubah menjadi data interval. Dalam lembar validasi disediakan lima pilihan untuk memberikan tanggapan tentang kualitas produk yang dikembangkan, yaitu: Sangat Valid (5), valid (4), Cukup Valid (3), Kurang Valid (2), Tidak Valid (1).

Skor yang diperoleh dari validator dijumlahkan menjadi skor aktual, untuk melihat kategorisasi skor digunakan acuan sebagaimana tertera pada Tabel 1 .

Tabel 1. Kategori Nilai Validasi

\begin{tabular}{ccc}
\hline Interval Skor & Nilai & Kategori \\
\hline $4<$ XLKS $\leq 5$ & A & Sangat Valid \\
$3,3<$ XLKS $\leq 4$ & B & Valid \\
$2,6<$ XLKS $\leq 3,3$ & C & Cukup Valid \\
$1,9<$ XLKS $\leq 2,6$ & D & Kurang Valid \\
$1 \leq$ XLKS $\leq 1,9$ & E & Tidak Valid \\
\hline
\end{tabular}

Kepraktisan perangkat yang dikembangkan diukur berdasarkan hasil penilaian dari guru mengenai kepraktisan produk pada setiap penerapannya di kelas. Berdasarkan item pertanyaan dalam instrumen penilaian kepraktisan pembelajaran, dibuat kategori kepraktisan dari buku guru. Berdasarkan hasil perhitungan skor penilaian, perangkat pembelajaran hasil pengembangan dikatakan memiliki derajat kepraktisan yang baik, jika hasil penilaian guru berada pada kategori minimal praktis.

Kepraktisan perangkat pembelajaran hasil pengembangan juga diukur berdasarkan hasil penilaian siswa yang diperoleh dari lembar penilaian kepraktisan perangkat dan pelaksanaan pembelajaran oleh siswa. Analisis dilakukan dengan membuat kategori tingkat kepraktisan dari siswa. Penilaian ditentukan menjumlahkan seluruh skor nilai dari siswa menjadi skor kepraktisan dari siswa. Perangkat yang dikembangkan dikatakan praktis jika $80 \%$ siswa memberikan penilaian yang menunjukkan bahwa perangkat pembelajaran memperoleh skor dalam kategori praktis. Selanjutnya dilakukan perhitungan persentase skor aktual berdasarkan hasil penilaian siswa pada setiap aspek.

Tabel 2. Kategori Nilai Kepraktisan

\begin{tabular}{ccc}
\hline Interval (\%) & Nilai & Kategori \\
\hline $86-100$ & A & Sangat Praktis \\
$71-85$ & B & Praktis \\
$56-70$ & C & Cukup Praktis \\
$41-55$ & D & Kurang Praktis \\
$\leq 40$ & E & Tidak Praktis \\
\hline
\end{tabular}

Data yang diperoleh dari pemberian angket kepada siswa ditampilkan dalam bentuk 
tabel, selanjutnya dicari rerata untuk masingmasing aspek yang ditanyakan, dengan cara sebagai berikut.

$\mathrm{P}=\frac{\mathrm{M}}{\mathrm{T}} \times 100 \%$

Keterangan:

$\mathrm{P} \quad=$ Persentasi pilihan siswa

$\mathrm{M} \quad=$ Frekuensi pilihan siswa

$\mathrm{T}=$ Total siswa yang mengisi angket

Respon siswa dikatakan positif bila paling sedikit $80 \%$ siswa menjawab "Ya". Respon guru dikatakan positif bila guru memberikan jawaban minimal baik pada setiap perangkat pembelajaran.

\section{HASIL DAN PEMBAHASAN}

Penelitian yang dilakukan adalah jenis penelitian pengembangan. Prototipe produk pengembangan yang dihasilkan berupa (1) model pembelajaran matematika berbasis konstruktivisme; (2) perangkat pendukung pembelajaran yakni rencana pelaksanaan pembelajaran (RPP), buku guru (BG), buku siswa (BS), dan lembar kerja siswa (LKS); serta (3) instrumen penilaian. Produk yang dihasilkan adalah pembelajaran matematika dengan pendekatan konstruktivisme dengan model pembelajaran cooperative learning tipe STAD yang valid, praktis, dan efektif.

Tabel 3. Hasil Validasi Instrumen Penelitian

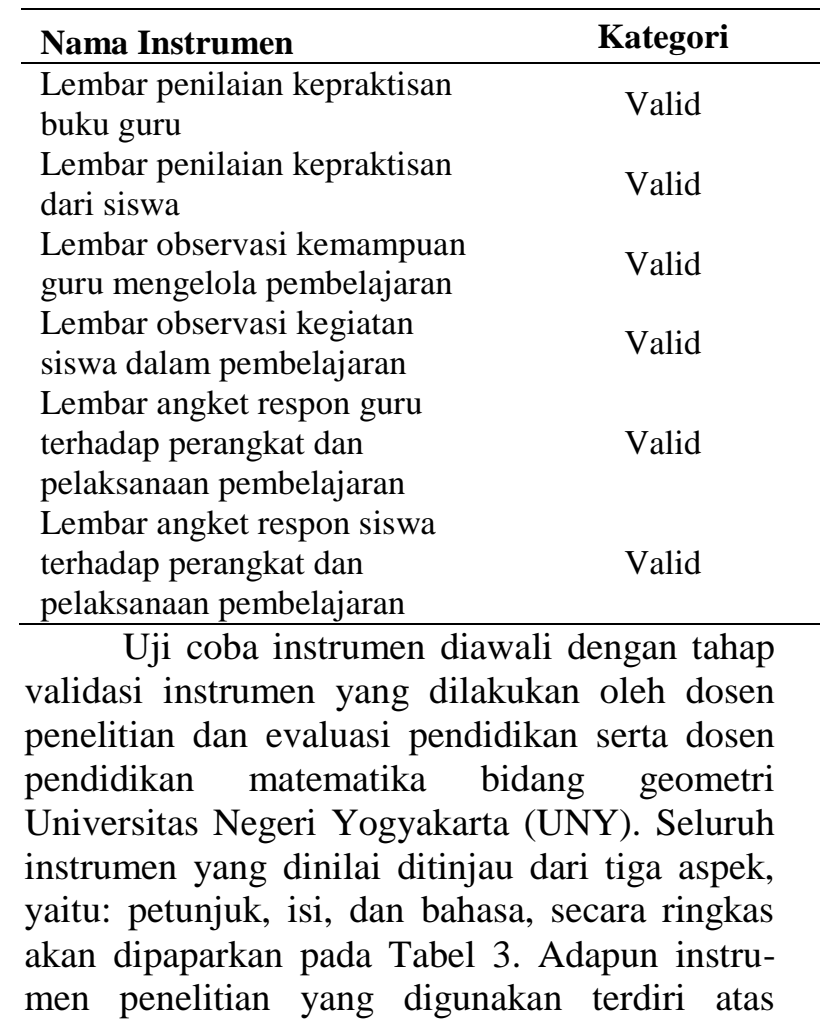

lembar penilaian kepraktisan buku guru, lembar penilaian kepraktisan dari siswa, lembar observasi kemampuan guru mengelola pembelajaran, lembar observasi kegiatan siswa dalam pembelajaran, lembar angket respon guru terhadap perangkat dan pelaksanaan pembelajaran dan lembar angket respon siswa terhadap perangkat.

Berdasarkan hasil validasi instrumen yang disajikan pada Tabel 3, terlihat bahwa masingmasing instrumen berada pada kategori valid sehingga instrumen penelitian tersebut dapat digunakan untuk melaksanakan langkah penelitian selanjutya.

Lembar penilaian kepraktisan buku guru digunakan oleh validator untuk memberikan penilaian terhadap tingkat kepraktisan buku guru yang digunakan. Lembar penilaian kepraktisan dari siswa digunakan oleh setiap siswa pada setiap akhir pembelajaran. Lembar observasi kemampuan guru mengelola pembelajaran diisi oleh observer pada setiap pertemuan dalam kegiatan pembelajaran. Lembar observasi kegiatan siswa juga diisi oleh observer untuk memberikan penilaian terhadap kegiatan siswa setiap pembelajaran berlangsung. Lembar angket respon guru terhadap perangkat dan pelaksanaan pembelajaran diisi oleh guru model untuk memberikan penilaian terhadap perangkat pembelajaran pada setiap pertemuan. Perangkat yang dimaksud meliputi buku guru, RPP, dan LKS. Lembar angket respon siswa terhadap perangkat dan pelaksanaan pembelajaran diberikan dan diisi oleh siswa untuk memberikan penilaian tingkat kepraktisan terhadap buku siswa yang digunakan pada setiap pertemuan pembelajaran.

Perangkat pembelajaran yang terdiri atas RPP, Buku Guru Buku Siswa Lembar Kegiatan Siswa dan Tes Hasil Belajar memiliki kategori minimal valid. Adapun rincian hasil penilaian produk hasil pengembangan diperlihatkan pada tabel-tabel berikut.

Tabel 4. Skor Validasi RPP

\begin{tabular}{lccc}
\hline \multirow{2}{*}{ Aspek } & \multicolumn{3}{c}{ Validator } \\
\cline { 2 - 4 } & V1 & V2 & V3 \\
\hline Kesesuaian dengan buku & 3,88 & 4 & 4,38 \\
Bahasa & 5 & 4 & 4,63 \\
Isi & 4,19 & 4 & 4,35 \\
Alokasi Waktu & 5 & 4 & 4 \\
Manfaat & 5 & 4 & 5 \\
\hline Rata-rata & \multicolumn{3}{c}{4,36} \\
\hline
\end{tabular}

Tabel 4 menunjukkan hasil penilaian 3 validator terhadap RPP hasil pengembangan. RPP dinilai berdasarkan beberapa aspek yaitu 
kesesuaian dengan buku, bahasa, isi, alokasi waktu dan manfaat. Berdasarkan hasil penilaian validator, diperoleh skor rata-rata sebesar 4,36 sehingga RPP hasil pengembangan memiliki kategori sangat valid.

Tabel 5. Skor Validasi Buku Guru

\begin{tabular}{lccc}
\hline \multirow{2}{*}{\multicolumn{1}{c}{ Aspek yang Dinilai }} & \multicolumn{3}{c}{ Validator } \\
\cline { 2 - 4 } & V1 & V2 & V3 \\
\hline Format Buku & 4,14 & 4 & 4 \\
Ilustrasi Tata Letak & 4 & 4 & 4 \\
Isi Buku & 4 & 3,79 & 4 \\
Bahasa dan Tulisan & 4 & 3,5 & 4 \\
Manfaat dan Kegunaan & 4,5 & 4 & 4 \\
\hline Rata-rata & \multicolumn{3}{c}{3,98} \\
\hline \multicolumn{1}{c}{ Selanjutnya, }
\end{tabular}

Selanjutnya, hasil penilaian validator terhadap buku guru ditinjau dari aspek format, ilustrasi, isi buku, bahasa dan tulisan serta manfaat dan kegunaan. Berdasarkan Tabel 5, skor hasil penilaian validator untuk buku guru sebesar 3,98. Dapat disimpulkan bahwa buku guru hasil pengembangan terkategori valid.

Tabel 6. Skor Validasi Buku Siswa

\begin{tabular}{lccc}
\hline \multirow{2}{*}{ Aspek yang Dinilai } & \multicolumn{3}{c}{ Validator } \\
\cline { 2 - 4 } & V1 & V2 & V3 \\
\hline Format Buku & 4 & 4 & 4,33 \\
Isi Buku & 4 & 3,9 & 4,05 \\
Bahasa dan Tulisan & 4 & 4 & 4,6 \\
Ilustrasi dan Tata Letak & 4 & 4 & 4 \\
Manfatat/ Kegunaan & 4,5 & 4 & 4 \\
\hline Rata-rata & \multicolumn{3}{c}{4,092} \\
\hline
\end{tabular}

Berdasarkan tabel 6, terlihat bahwa skor rata-rata penilaian validator terhadap buku siswa sebesar 4,092. Dengan demikian, buku siswa hasil pengembangan memiliki kategori sangat valid.

Tabel 7. Skor Validasi LKS

\begin{tabular}{lccc}
\hline \multirow{2}{*}{ Aspek yang Dinilai } & \multicolumn{3}{c}{ Validator } \\
\cline { 2 - 4 } & V1 & V2 & V3 \\
\hline Format LKS & 4,14 & 4 & 4 \\
Rata-rata Keseluruhan & 4,24 & 3,94 & 3,88 \\
Bahasa dan Tulisan & 4 & 4 & 4 \\
Ilustrasi ,Tata Letak & 4,25 & 4 & 4 \\
Manfaat dan Kegunan & 5 & 4 & 4 \\
\hline Rata-rata & \multicolumn{3}{c}{4,10} \\
\hline
\end{tabular}

Tabel 8. Skor Validasi Buku Guru

\begin{tabular}{lcccc}
\hline \multirow{2}{*}{ Aspek } & \multicolumn{3}{c}{ Validator } & \multirow{2}{*}{ Rata-rata } \\
\cline { 2 - 4 } & V1 & V2 & V3 & \\
\hline Format & 3,8 & 4 & 4,3 & 4,1 \\
Ilustrasi & 4 & 4 & 4,5 & 4,2 \\
Isi & 4 & 3,7 & 4,4 & 4,1 \\
Bahasa, & 4 & 3,5 & 4,7 & 4,1 \\
Manfaat & 4 & 4 & 4 & 4 \\
\hline \multicolumn{5}{c}{ Kesimpulan } \\
\hline
\end{tabular}

Berdasarkan Tabel 7, terlihat bahwa skor rata-rata hasil penilaian validator terhadap LKS sebesar 4,10. Dapat disimpulkan bahwa LKS hasil pengembangan memiliki kategori sangat valid.

Tabel 8 menunjukkan hasil penilaian buku guru oleh validator. Terlihat bahwa skor ratarata penilaian validator terhadap buku guru sebesar 4,1. Dapat disimpulkan bahwa buku guru hasil pengembangan memiliki kategori sangat Valid.

Selanjutnya, Tes Hasil Belajar yang digunakan di akhir uji coba juga divalidasi. Berikut skor hasil validasi THB disajikan dalam Tabel 9.

Tabel 9. Skor Validasi THB

\begin{tabular}{lccc}
\hline \multirow{2}{*}{\multicolumn{1}{c}{ Aspek }} & \multicolumn{3}{c}{ Validator } \\
\cline { 2 - 4 } & V1 & V2 & V3 \\
\hline Format & 3,83 & 4 & 4,33 \\
Ilustrasi, Letak & 4 & 4 & 4,5 \\
Isi & 4 & 3,73 & 4,45 \\
Bahasa,Tulisan & 4 & 3,5 & 4,75 \\
Manfaat/ Kegunaan & 4 & 4 & 4 \\
\hline \multicolumn{1}{c}{ Rata-rata } & \multicolumn{3}{c}{4,07} \\
\hline
\end{tabular}

Validasi terhadap tes hasil belajar ditinjau dari beberapa aspek. Aspek tersebut adalah format, Ilustrasi tata letak, Isi dan kesesuaian materi, bahasa dan tulisan serta manfaat atau kegunaan. Berdasarkan Tabel 9 terlihat bahwa rata-rata skor hasil penilaian validator terhadap THB sebesar 4,07. Dengan demikian, THB hasil pengembangan memiliki kategori sangat valid.

Hasil validasi perangkat pembelajaran yang berupa skor penilaian dari validator terhadap RPP, Buku Guru, Buku Siswa, LKS dan Tes Hasil belajar dirangkum pada Tabel 10.

Tabel 10. Data Validasi Perangkat Pembelajaran

\begin{tabular}{ccccc}
\hline RPP & BG & BS & LKS & THB \\
\hline $\begin{array}{c}\text { Sangat } \\
\text { valid }\end{array}$ & Valid & $\begin{array}{c}\text { Sangat } \\
\text { valid }\end{array}$ & $\begin{array}{c}\text { Sangat } \\
\text { valid }\end{array}$ & $\begin{array}{c}\text { Sangat } \\
\text { valid }\end{array}$ \\
\hline
\end{tabular}

Data pada Tabel 10 merupakan hasil validasi perangkat pembelajaran hasil pengembangan. Setiap perangkat perangkat pembelajaran hasil pengembangan yang berupa RPP, Buku Guru, Buku Siswa, Lembar Kegiatan Siswa dan Tes Hasil Belajar memiliki kategori minimal valid sehingga layak untuk digunakan pada proses pembelajaran dalam uji coba lapangan.

Untuk memperoleh data mengenai kepraktisan perangkat pembelajaran, digunakan lembar penilaian kepraktisan perangkat yang diisi oleh guru dan siswa pada setiap akhir pem- 
belajaran. Adapun data hasil penilaian kepraktisan perangkat pembelajaran disajikan pada Tabel 11.

Tabel 11. Data Kepraktisan Perangkat Pembelajaran

\begin{tabular}{cccc}
\hline RPP & BG & BS & LKS \\
\hline Sangat & \multirow{2}{*}{ Praktis } & Sangat & Sangat \\
Praktis & & Praktis & Praktis \\
\hline
\end{tabular}

Berdasarkan Tabel 11, terlihat bahwa perangkat pembelajaran hasil pengembangan berupa RPP, LKS dan buku siswa memiliki kriteria Sangat Praktis, sedangkan buku guru memiliki kriteria praktis.

Uji lapangan terhadap Tes hasil Belajar dilakukan pada kelas IX di SMP Pembangunan Piyungan Yogyakarta. Pada pelaksanaan, waktu yang diperlukan siswa untuk menjawab soal siswa membutuhkan waktu kurang lebih 60 menit. Dari pertimbangan tersebut, maka untuk THB akan diadakan selama 80 menit. THB diestimasi nilai reliabilitas, tingkat kesulitan dan daya bedanya. Ringkasan hasil perhitungan reliabilitas, tingkat kesulitan dan daya beda dapat dilihat pada Tabel 12.

Tabel 12. Analisis Data Tes hasil Belajar

\begin{tabular}{lccc}
\hline \multicolumn{1}{c}{ Uji } & THB 1 & THB 2 & THB 3 \\
\hline Reliabilitas & 0,391 & 0,383 & 0,467 \\
Tingkat Kesulitan & Sedang & Sedang & Sedang \\
Daya Beda & Diterima & Diterima & Diterima \\
\hline
\end{tabular}

Berdasarkan Tabel 12, terlihat bahwa THB 1, THB 2 dan THB 3 memiliki tingkat kesulitan sedang. Sementara daya beda dalam kategori diterima dengan baik. Kriteria keefektifan Tes Hasil Belajar dikatakan tercapai jika paling sedikit $80 \%$ siswa mencapai tingkat hasil belajar minimal baik. Secara ringkas hasil THB siswa dapat dilihat pada Tabel 13.

Tabel 13. Hasil Analisis Data Tes Hasil Belajar

\begin{tabular}{cccc}
\hline THB & Siswa lulus & Jumlah siswa & Persentase \\
\hline 1 & 25 & 28 & 89 \\
2 & 28 & 28 & 100 \\
3 & 28 & 28 & 100 \\
\hline
\end{tabular}

Tabel 13 menunjukkan bahwa hasil THB siswa pada THB 1,2 dan 3 sudah memenuhi kriteria yang ditetapkan meskipun masih ada 3 siswa yang belum lulus pada tes tersebut. THB siswa menunjukkan rata-rata tingkat kelulusan pada masing-masing tes $96 \%$ sehingga Tes Hasil Belajar masuk dalam kategori sangat efektif.
Tabel 13 Hasil Analisis Data Observasi Kemampuan Guru

\begin{tabular}{ccccccc}
\hline & \multicolumn{7}{c}{ Pertemuan ke... } \\
\cline { 2 - 7 } & $\mathbf{1}$ & $\mathbf{2}$ & $\mathbf{3}$ & $\mathbf{4}$ & $\mathbf{5}$ & $\mathbf{6}$ \\
\hline Skor & 88,5 & 89 & 84,5 & 85,5 & 89 & 90,5 \\
Skala 5 & 3,85 & 3,87 & 3,67 & 3,72 & 3,87 & 3,93 \\
Kategori & Baik & Baik & Baik & Baik & Baik & Baik \\
\hline
\end{tabular}

Kemampuan guru dalam menyampaikan pembelajaran dinilai melalui lembar observasi kemampuan guru. Seluruh skor pada lembar penilaian instrumen yang telah diisi oleh dua observer dijumlahkan menjadi skor aktual observasi kemampuan guru. Pembelajaran dikatakan praktis jika minimal skor dari dua observer pada kategori minimal baik, dengan skor lebih dari 84,5. Analisis data hasil dapat dilihat pada Tabel 13.

Untuk menjamin reliabilitas hasil pengamatan, dilakukan analisis reabilitas antar hasil pengamatan dengan menggunakan formula Percentage of Agreement (PA) terhadap hasil pengamatan pada setiap pembelajaran. Analisis data percentage of agreement terdapat pada tabel 14.

Tabel 14. Analisis Kesepakatan Antar Penilai Terhadap Observasi Kemampuan Guru

\begin{tabular}{ccc}
\hline Pertemuan & $\begin{array}{c}\text { Percentage of } \\
\text { Agreement }\end{array}$ & Kategori \\
\hline P1 & 0,99 & Reliabel \\
P2 & 1,00 & Reliabel \\
P3 & 0,99 & Reliabel \\
P4 & 0,94 & Reliabel \\
P5 & 0,96 & Reliabel \\
P6 & 0,97 & Reliabel \\
\hline
\end{tabular}

Berdasarkan Tabel 13 terlihat bahwa skor dari dua observer pada setiap pertemuan pembelajaran memenuhi kriteria reliabel. Sehingga data hasil observasi dari kedua observer merupakan data yang dapat digunakan untuk tahap selanjutnya pada penelitian ini

Berdasarkan uraian hasil analisis yang telah dipaparkan. Terlihat bahwa perangkat pembelajaran matematika berbasis konstruktivisme, dalam penelitian ini menggunakan model cooperative learning tipe STAD, hasil pengembangan memenuhi kriteria valid, praktis dan efektif. Pembelajaran menggunakan model ni, mampu meningkatkan prestasi belajar siswa karena dalam STAD, siswa diberi kesempatan yang lebih luas untuk berdiskusi dan membangun pemahaman mereka sendiri bersama teman-teman sekelompoknya. Selain itu, siswa memiliki kesempatan untuk melatih keper- 
cayaan diri mereka, kemampuan kerja sama serta kemampuan intrapersonal mereka dalam kegiatan pembelajaran dalam kelompok. Dengan demikian pembelajaran akan menjadi lebih bermakna. Hal ini sejalan dengan pendapat Shininger (2006), Arends (2009) dan Badrun \& Hartono (2013) yang menyatakan bahwa STAD efektif untuk meningkatkan berbagai sikap positif serta prestasi akademis siswa.

\section{SIMPULAN}

Berdasarkan hasil penelitian dan pembahasan, diperoleh simpulan bahwa perangkat pembelajaran matematika berbasis konstruktivisme dengan model koperatif tipe STAD hasil pengembangan memenuhi kriteria valid, praktis, dan efektif. Hasil validasi menunjukkan bahwa perangkat pembelajaran yang dikembangkan yakni RPP, BG, BS, LKS layak digunakan dengan kategori valid, praktis dan efektif, sedangkan THB terkategori valid dan reliabel. Hasil penilaian kepraktisan menunjukkan bahwa berdasarkan penilaian guru, perangkat pembelajaran hasil pengembangan terkategori sangat praktis, sedangkan hasil penilaian kepraktisan oleh siswa berkategori praktis. Pembelajaran juga efektif yakni siswa yang lulus lebih dari $80 \%$

\section{DAFTAR PUSTAKA}

Allen, M.J \& Yen, W.M (1979). Introduction to measurement theory. California: Brooks/ Cole Publishing Company.

Arends, R. I. (2009). Learning to teach (9th ed.). New York: McGraw-Hill.

Arends, R. I. \& Kilcher, A.(2010). Teaching for student learning: Becoming an accomplished teacher. New York, NY: Routledge Taylor \& Francis Group.

Azni, T.N. (2015). Pengembangan perangkat pembelajaran trigonometri berbasis strategi pembelajaran inkuiri melalui model pembelajaran kooperatif tipe STAD. Jurnal Riset Pendidikan Matematika, 2 (2), 285.

Badrun, \& Hartono. (2013) Keefektifan metode pembelajaran kooperatif model STAD ditinjau dari prestasi dan motivasi belajar siswa di kelas VII SMP. Pythagoras, 8(2), 120-134.
Ebel (1979). Essentials of educational measurement 3thedition. New Jersey: Prentice Hall.

Glasersfeld. (2003). Radical constructivism: a way of knowing and learning. studies in mathematics education. New York, NY: The Falmer Press.

Hudojo, H. (1998). Pembelajaran matematika menurut pandangan konstruktivistik. Makalah disajikan dalam Seminar Nasional Upaya Meningkatkan Peran Pendidikan Matematika dalam Menghadapi Globalisasi di PPs IKIP Malang.

Marsigit. (2007). Mathematics teachers professional development through lesson study in Indonesia: Eurasia Journal of Mathematics, Science \& Technology Education, 3(2).

Marsigit. (2010). Developing teacher training textbooks for lesson study in Indonesia. APEC-Tsukuba International Conference: Innovation of Mathematics Teaching and Learning through Lesson StudyConnection between Assessment and Subject Matter di Tokyo, Jepang.

Muijs, D., \& Reynold, D. (2011). Effective teaching: Evidence and practice (3rd ed.). London: SAGE.

Nikou, Anthony, J. \& Brookhart, S. (2007). Educational assessment of students. Upper Saddle River: Pearson Prentince Hall.

Nitko, A J \& Brookhart, S. (2007). Educational assessment of students. Upper Saddle River, NJ: Pearson Prentice Hall.

Rostika. D (2008). Pembelajaran volume bangun ruang melalui pendekatan konstruktivisme untuk siswa sekolah dasar. Jurnal Pendidikan Dasar, 9(1).

Shininger, K. A. (2006), The benefits of using STAD in a middle school mathematics classroom. Clinton: Defiance College.

Slavin, R. E. (1995). Cooperative learning: Theory, research, and practice (2nd ed.). Boston: Alllyn and Bacon.

Suparno. (1997). Filsafat konstruktivisme dalam pendidikan. Yogyakarta: Kanisius. 